\title{
Pleiotropic Compensation in the Regulation of Extracellular Protein Formation by a Low $\alpha$-Toxin-producing Variant of Staphylococcus aureus (Wood 46)
}

\author{
By GEOFFREY COLEMAN \\ Department of Biochemistry, Nottingham University Medical School, Clifton Boulevard, \\ Nottingham NG7 2 UH
}

(Received 3 June 1980)

\begin{abstract}
The changes in bacterial density, total extracellular protein and haemolysin produced by bacteria from overnight cultures of Staphylococcus aureus (Wood 46) and a low $\alpha$-toxin-producing variant suspended in fresh medium were followed at $37^{\circ} \mathrm{C}$. Although five extracellular proteins were produced at a reduced level by the variant ( $\alpha$-toxin formation was reduced more than tenfold), the differential rates of total extracellular protein formation by the two organisms were identical. The results are consistent with a common regulatory mechanism for extracellular protein formation in which a pleiotropic compensation may occur in order to saturate the extracellular protein-producing capability.
\end{abstract}

\section{INTRODUCTION}

The characteristics of extracellular protein formation by Staphylococcus aureus (Wood 46) (Abbas-Ali \& Coleman, 1977a, b; Coleman \& Abbas-Ali, 1977) are consistent with a regulatory mechanism based on 'competition' as proposed by Coleman et al. (1975). Thus, at high growth rates, which are accompanied by a high rate of cellular protein synthesis, there is an accompanying low rate of extracellular protein formation. However, as the growth rate is reduced after exponential growth, there is a corresponding increase in the rate of extracellular protein production.

It is relevant to the above proposal that Yoshikawa et al. (1974) observed a pleiotropic increase in the activities of several extracellular toxins and enzymes in mutants of $S$. aureus. The growth rates of the mutant (hyperproducer) strains were almost the same as the growth rate of the parent organism and catabolite repression did not appear to be involved in the control of the synthesis of the extracellular proteins. These authors favoured the possibility of regulation by a common, as yet undefined, mechanism. Coleman \& Abbas-Ali (1977) noted the possible interpretation of these observations in terms of the 'competition' model of Coleman et al. (1975). Thus, if mutation caused the loss of a single major extracellular product, extra biosynthetic capacity would be available for producing additional amounts of all other extracellular proteins. If this explanation is correct, then the parent and mutant strains might be expected to retain identical characteristics of total extracellular protein production.

It has now been possible to test this prediction by comparing the parent Wood 46 strain of $S$. aureus with a low $\alpha$-toxin-producing variant of the same organism.

\section{METHODS}

Organisms. Staphylococcus aureus (Wood 46) (NCTC 7121) was used together with a stable low $\alpha$-toxin-producing variant. The latter was isolated from a culture of the parent organism which had been grown in liquid medium, for $24 \mathrm{~h}$ at $37^{\circ} \mathrm{C}$, in the presence of ethidium bromide, a non-mutagenic inhibitor of DNA synthesis. 
Growth conditions. Cultures were grown for $16 \mathrm{~h}$ at $37^{\circ} \mathrm{C}$, with shaking, in a medium which contained Tryptone Soya Broth (Oxoid; $3 \%$, w/v), trace metal ion solution $\left(0.2 \mathrm{ml} 1^{-1}\right)$, vitamin solution $\left(40 \mathrm{ml} 1^{-1}\right)$ and $\mathrm{MgSO}_{4}(0.8 \mathrm{mM})$, as described by Abbas-Ali \& Coleman $(1977 \mathrm{a})$. The trace metal ion solution consisted of $0.1 \mathrm{mg} \mathrm{CoCl} 2.6 \mathrm{H}_{2} \mathrm{O}, 0.1 \mathrm{mg} \mathrm{MnCl}_{2} .4 \mathrm{H}_{2} \mathrm{O}, 0.01 \mathrm{mg} \mathrm{CuSO}{ }_{4} .5 \mathrm{H}_{2} \mathrm{O}$ and $0.1 \mathrm{mg}$ ammonium molybdate in 1.01 water. The vitamin solution contained $0.1 \mathrm{mg}$ riboflavin and $1.0 \mathrm{mg}$ each of inositol, biotin, choline chloride, folic acid, nicotinamide, calcium pantothenate, pyridoxal 5-phosphate and thiamin hydrochloride in 1.01 water.

The bacteria from $40 \mathrm{ml}$ culture were harvested by centrifugation at $6500 \mathrm{~g}$ for $3 \mathrm{~min}$ at room temperature, washed once by resuspension in fresh medium at $37^{\circ} \mathrm{C}$, and finally resuspended in fresh medium to the original culture volume. The resuspended cells were then incubated, at $37^{\circ} \mathrm{C}$ with shaking, and samples were taken for assay at $30 \mathrm{~min}$ intervals over a $3 \mathrm{~h}$ period.

Bacterial density determination. The method of Stormonth \& Coleman (1972) was employed.

Extracellular protein estimation. The protein content of culture supernatant fractions was determined by the method of Sedmak \& Grossberg (1977) as described by Coleman et al. (1978).

Haemolytic activity. The haemolysin content of culture supernatant fractions was estimated by the method of Bernheimer \& Schwartz (1963).

Sodium dodecyl sulphate (SDS)-polyacrylamide gel electrophoresis. This was carried out on dialysed, lyophilized samples of the supernatant fractions of overnight cultures as described by Laemmli (1970).

\section{RESULTS}

Supernatant fractions from $16 \mathrm{~h}$ cultures of the parent and variant strains were subjected to SDS-polyacrylamide gel electrophoresis. Different track loadings were chosen such that the bands corresponding to the highest molecular weight proteins were of the same intensity. It was considered that this presented the best comparison of the relative distribution profiles for each preparation (Fig. 1). The protein band patterns showed that the parent organism and the low $\alpha$-toxin-producing variant produce the same extracellular proteins. However, in the variant, five components (a to e), including the $\alpha$-toxin, were present in reduced amounts relative to the levels produced by the parent organism.

The changes in bacterial density, total extracellular protein and haemolysin were followed over $3 \mathrm{~h}$ in cultures prepared by resuspension of washed cells in fresh medium. Similar patterns of increase in bacterial density and total extracellular protein formation were achieved by the two organisms and over the $3 \mathrm{~h}$ incubation the bacterial density approximately doubled in each case (Fig. 2). However, with respect to the haemolysin there was a marked difference; whilst the parent organism secreted haemolysin corresponding to 1060 haemolytic units $\mathrm{ml}^{-1}$ the variant produced only 84 haemolytic units $\mathrm{ml}^{-1}$.

The differential rates of haemolysin formation and total extracellular protein production in the two cases are shown in Fig. 3. 'Differential rate' is defined in this particular context as the ratio of the amount of haemolysin or exoprotein synthesized to the amount of bacterial mass appearing within the same period of time (Monod et al., 1952). It can be seen that whilst the plots of haemolysin formed against increase in bacterial density were completely dissimilar (Fig. $3 a$ ) the differential rates of total extracellular protein formation by the two organisms were identical (Fig. $3 b$ ).

\section{DISCUSSION}

The foregoing results show that changes in $S$. aureus (Wood 46), which resulted in the formation of a stable variant, reduced the ability of the organism to produce five different protein components (Fig. 1, a to e). The most pronounced change was in the most abundant parent strain component, the $\alpha$-toxin (Fig. 1, a), shown by quantitative assay to represent a reduction in haemolysin production of more than $90 \%$ (Fig. 2).

If the extracellular proteins of $S$. aureus (Wood 46) are each subject to independent control, then, since $\alpha$-toxin and the other four extracellular components are produced at a reduced level by the variant organism, a reduction in the differential rate of total extracellular protein formation would be expected. However, as shown in Fig. $3(b)$, this was not the case 


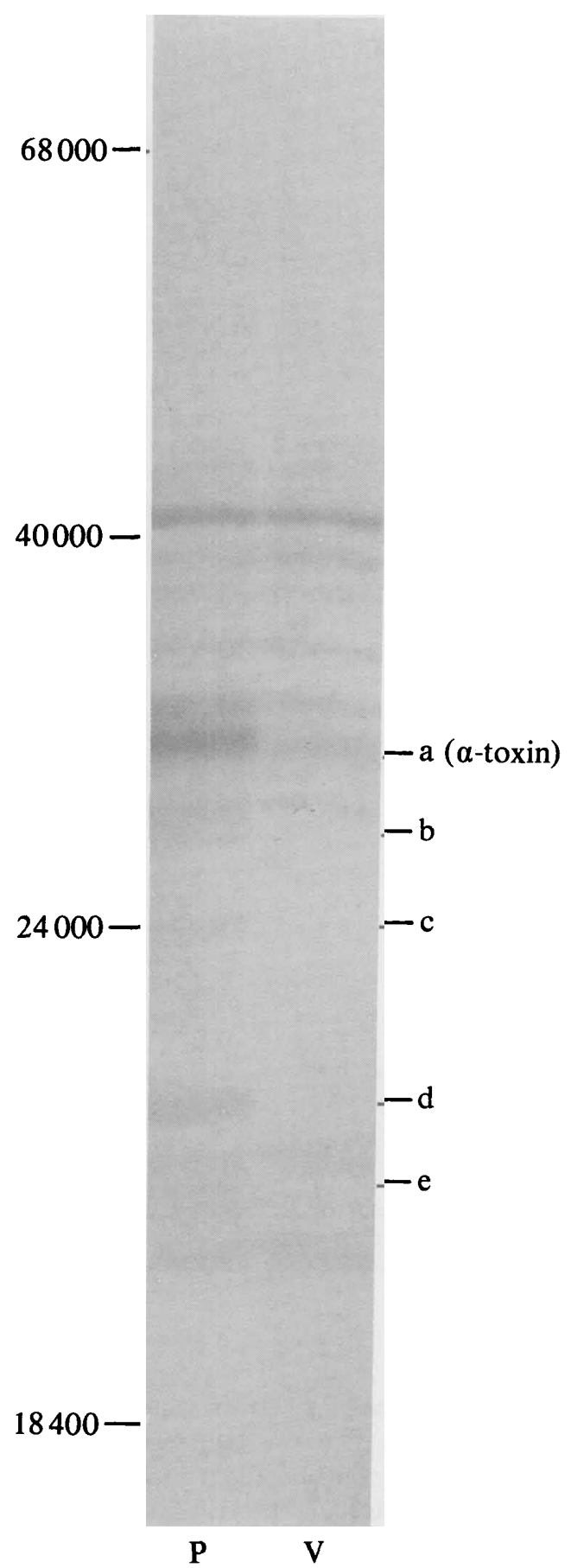

Fig. 1. SDS-polyacrylamide gel electrophoresis of the extracellular proteins produced by the parent Wood 46 strain of $S$. aureus (P) and a low a-toxin-producing variant (V). The positions of marker proteins are shown and indicated by their molecular weights. The positions of those components of the variant extracellular protein present at reduced levels are marked (a to e). The sample wells of the two tracks, $P$ and $V$, were loaded with 80 and $60 \mu \mathrm{g}$ protein, respectively. 


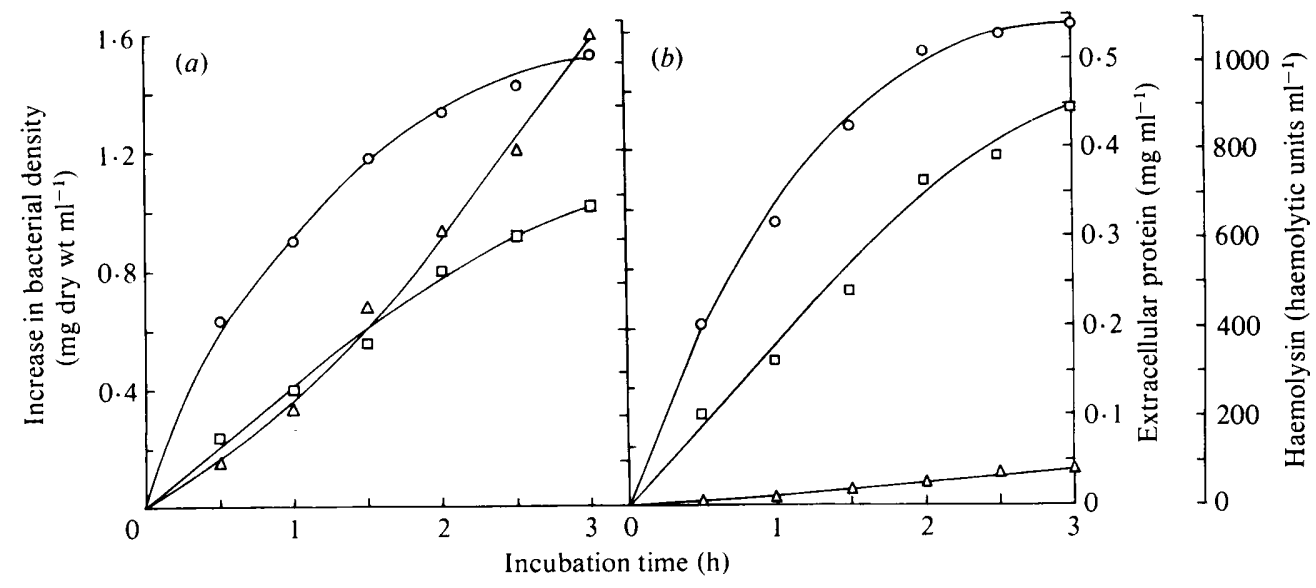

Fig. 2. Increase in bacterial density $(O)$ in relation to the secretion of extracellular protein $(\square)$ and haemolysin $(\triangle)$ by washed cells from overnight cultures of $S$. aureus (Wood 46) $(a)$ and a low $a$-toxin-producing variant $(b)$ resuspended in fresh medium.
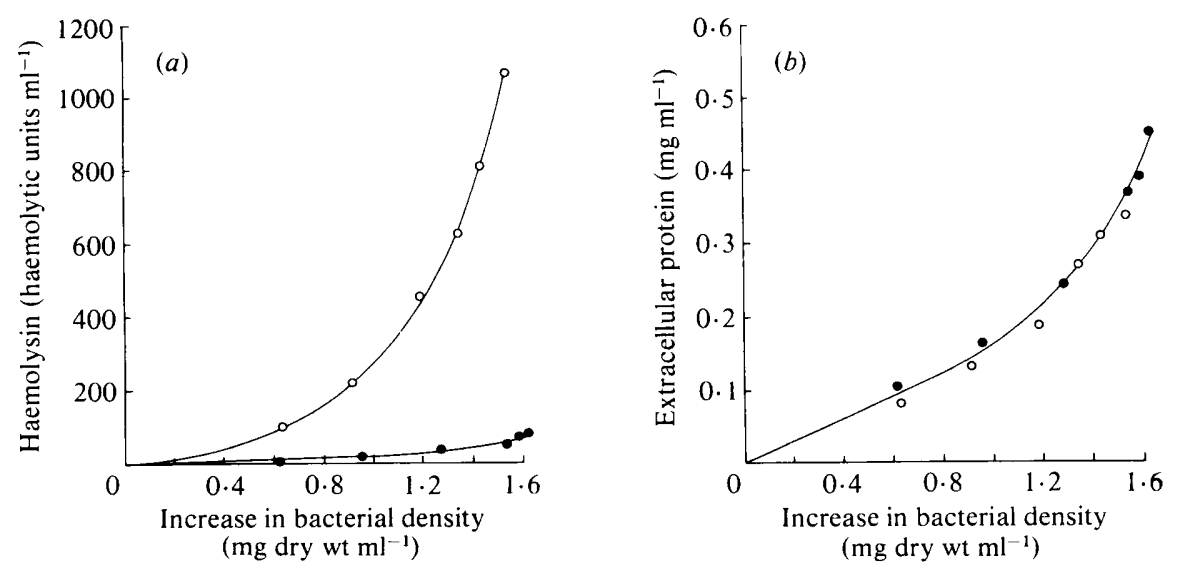

Fig. 3. Relationship between increase in bacterial density and haemolysin production $(a)$ or extracellular protein formation $(b)$ by washed cells from overnight cultures of $S$. aureus (Wood 46) (O) and a low $\alpha$-toxin-producing variant $(O)$ resuspended in fresh medium.

and there was no detectable difference between the rates of extracellular protein formation in the two organisms. This suggests that the reduction in ability to produce five protein components is compensated for by an increased ability to produce all other extracellular proteins in order to saturate an extracellular protein-producing capability.

This conclusion is consistent with the pleiotropic alteration of multiple functions reported by Yoshikawa et al. (1974) who also suggested a common regulatory mechanism for the synthesis and release of extracellular enzymes. Both observations would clearly agree with the idea inherent in the 'competition' model for the regulation of extracellular protein formation proposed by Coleman et al. (1975).

This work was supported by a grant from the Medical Research Council. 


\section{REFERENCES}

Abbas-Ali, B. \& Coleman, G. (1977a). The characteristics of extracellular protein secretion by Staphylococcus aureus (Wood 46) and their relationship to the regulation of a-toxin formation. Journal of General Microbiology 99, 277-282.

AbBas-Ali, B. \& Coleman, G. (1977b). Nutritional shifts and their effect on the secretion of extracellular proteins by Staphylococcus aureus (Wood 46). Biochemical Society Transactions 5, 420-422.

Bernheimer, A. W. \& Schwartz, L. L. (1963). Isolation and composition of staphylococcal alpha toxin. Journal of General Microbiology 30, 455468.

Coleman, G. \& AbBas-Ali, B. (1977). Comparison of the patterns of increase in $\alpha$-toxin and total extracellular protein by Staphylococcus aureus (Wood 46) grown in media supporting widely differing growth characteristics. Infection and Immunity 17, 278-281.

Coleman, G., Brown, S. \& Stormonth, D. A. (1975). A model for the regulation of bacterial extracellular enzyme and toxin biosynthesis. Journal of Theoretical Biology 52, 143-148.

Coleman, G., Jakeman, C. M. \& Martin, N. (1978). Patterns of total extracellular protein secretion by a number of clinically isolated strains of Staphylococcus aureus. Journal of General Microbiology 107, 189-192.

LAEMMLI, U. K. (1970). Cleavage of structural proteins during the assembly of the head of bacteriophage T4. Nature, London 227, 680-685.

Monod, J., Pappenheimer, A. M. \& Cohen-Bazire, G. (1952). La cinétique de la biosynthèse de la $\beta$-galactosidase chez $E$. coli considérée comme fonction de la croissance. Biochimica et biophysica acta 9, 648-660.

Sedmak, J. J. \& Grossberg, S. E. (1977). A rapid, sensitive and versatile assay for protein using Coomassie brilliant blue G250. Analytical Biochemistry 79, 544-552.

Stormonth, D. A. \& Coleman, G. (1972). A rapid and convenient method for the determination of cell densities of bacteria which form aggregates. Journal of General Microbiology 71, 407-408.

Yoshikawa, M., Matsuda, F., Naka, M., Mirofushi, E. \& Tsunematsu, Y. (1974). Pleiotropic alteration of activities of several toxins and enzymes in mutants of Staphylococcus aureus. Journal of Bacteriology 119, 117-122. 